\title{
Hospitalisation DueTo Lyme Disease: Case Series In British Forces Germany
}

\author{
BC Baker, AM Croft, CR Winfield
}

\begin{abstract}
Lyme disease is a tick-transmitted infection with disabling sequelae and important occupational health implications for a military workforce It is likely that some military patients with typical clinical signs remain undiagnosed and untreated. Prompt treatment with an antibiotic is essential, besides targeted education on preventing infection through avoiding exposure to tick bites. We describe four British Forces Germany personnel (two serving military personne, one adult civilian, one child) who during 2002-2003 required hospital inpatient treatment for Lyme disease. The epidemiology, pathogenesis, clinical features, diagnosis and treatment of the disease are discussed.
\end{abstract}

Key words: Lyme Disease, British Army, Borrelia burgdorferi, Occupational Health

\section{Introduction}

Lyme disease is a multi-system illness resulting from the bite of an I xodes or hardbodied tick (Figure 1) infected with spirochaetes of the genospecies B orrelia burgdorferi sensu lato (1). T he disease takes its name from the town of Lyme in Connecticut, USA.

Lyme disease is rare in Britain, with a mean of about 50 new cases reported in England and Wales each year (2). In mainland Europe the infection is more common, with especially high endemicity in southern Scandinavia, the $\mathrm{N}$ etherlands, parts of Germany and in eastern European states such as Austria and Slovenia (3). Lyme disease is, therefore, a threat to British troops and their families stationed in continental Europe.

We describe four British Forces Germany personnel who required hospital inpatient treatment for $L$ yme disease.

\section{Case One}

$\mathrm{H}$ istory and initial findings

Admitted in September 2002 to Allgemeines $\mathrm{K}$ rankenhaus, Viersen. The patient was a 46-year old male noncommissioned British Army officer. $\mathrm{He}$ complained of recent-onset neuroradicular symptoms in the shoulder girdle, radiating into both arms and into the neck, and of diffuse paraethesiae. $\mathrm{He}$ felt generally unwell, weak and apathetic.

$\mathrm{H}$ e gave a history of a tick bite some 5 to 6 weeks earlier, while off-duty, resulting in localised reddening which persisted for several weeks.

Physical examination showed localised reddening on the left upper arm. Auscultation of the heart and lungs was normal, and there was no focal neurological deficit, and no peripheral, sensory or motor

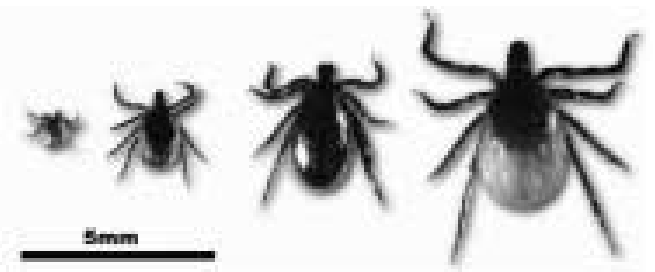

Fig1. D evelopmental stages of the I xodes tick (EU CALB).

deficits.

Investigations

Serology and CSF testing were both positive for $B$. burgdorferi IgG and IgM. ECG showed normal sinus rhythm of 70 beats per minute, with left axis deviation but no significant repolarisation abnormalities, and no blocks.

Treatment and progress

A diagnosis was made of radiculoneuritis secondary to L yme disease. The patient was treated with intravenous cefuroxime. $\mathrm{H}$ is symptoms had improved by the fifth day of antibiotic treatment, and his rash had disappeared. Discharged after 11 days.

\section{CaseTwo}

$\mathrm{H}$ istory and initial findings

Admitted in October 2002 to Allgemeines $\mathrm{K}$ rankenhaus, Viersen. The patient was a 46-year old female British Army officer. She had no previous illnesses of note, and no prior hospitalisations. She gave a history of dysaesthesia in both arms, with pins and needles and paraesthesiae in both hands. She complained of concentration difficulties and visual disturbances, and felt ill, tired and exhausted.

There was no history of tick bite, but physical examination showed typical erythema migrans on the right side of the chest, in the mid-axillary line. She was admitted with clinically suspected L yme disease. 
Investigations

Serology and CSF testing were negative for B. burgdorferi IgG and IgM. Western blotting was negative. ECG showed normal sinus rhythm of 70 beats per minute, with no significant repolarisation abnormalities, and no blocks. Echocardiography showed a normal sized heart, for her age.

Treatment and progress

The patient's symptoms, together with the classic erythema migrans rash, pointed to a clinical diagnosis of Stage $2 \mathrm{~L}$ yme disease. The patient was treated with intravenous ceftriaxon, later changed to oral doxycycline. D ischarged after 8 days.

\section{CaseThree}

$\mathrm{H}$ istory and initial findings

Two consecutive admissions, in February and $M$ arch 2003, to Zentrum fur K inderund-Jugendmedizin, Krefeld. The patient was a 12-year old female, the daughter of a non-commissioned British Army officer. She was investigated and diagnosed during the first admission, and treated during the second.

The patient gave a 6-month history of pain in her right hip, knee and ankle joints, with a more recent monoparesis of her right leg She also complained of blurred vision in her right eye. There was no history of tick bite.

Physical examination showed a drop-foot gait and reduced right gluteal muscular mass, with paresis of the right peroneal nerve. The patient was unable to lift her right foot, and had a dull feeling in the foot. The right plantar reflex could not be elicited.

Investigations

$\mathrm{N}$ ormal values for full blood screen, liver enzymes, electrolytes, creatinine, urea. Polio antibodies were detected but the results were consistent with previous immunisation. Serology was positive for B. burgdorferi IgG on ELISA and Western blot, but negative for IgM. CSF testing was positive for $\mathrm{B}$. burgdorferi IgG and IgM. Fundoscopy normal. MRI images of the cervical, thoracic and lumbar spines showed no evidence of an intraspinal or intracranial cause of the paresis.

Treatment and progress

On the first admission, a diagnosis of $L$ yme disease was made. During a second, twoweek admission the patient was treated with intravenous cefotaxime, together with intensive physiotherapy. Outpatient physiotherapy in a rehabilitation unit was recommended.

\section{Case Four}

$\mathrm{H}$ istory and initial findings

Admitted in July 2003 to Allgemeines
$\mathrm{K}$ rankenhaus, Viersen. The patient was a 48-year old female UK-based civilian, resident in Germany. She had made a complete recovery from a left-sided stroke one year previously, and complained now of recent-onset left-sided facial paresis, with diffuse neuroradicular symptoms in her shoulder girdle area. She felt ill, weak and tired.

She gave a history of a tick bite some 6 to 8 weeks earlier.

Physical examination was normal except for a facial palsy on the left.

\section{Investigations}

Serology was negative for B. burgdorferi IgG but positive for IgM. CSF testing was positive for B. burgdorferi IgG and IgM .

\section{Treatment and progress}

The symptoms and laboratory findings pointed to $L$ yme disease. The patient was treated with intravenous ceftriaxone for 14 days, and this led to resolution of her neuroradicular symptoms, and complete remission of her facial paresis.

\section{Discussion}

Epidemiology of Lyme disease

Humans acquire Lyme disease by cutaneous inoculation of spirochaeteinfected saliva, after being bitten by an infective vector tick. In Europe, the natural reservoir hosts of $B$. burgdorferi s.l. comprise nine small mammals (including several mice, the bank vole and shrews), seven medium-sized mammals (especially squirrels) and a number of birds (4).

The global distribution of Lyme disease closely matches the worldwide distribution of ticks of the Ix. ricinus complex, although the disease is often highly focal within endemic regions (5). High-risk areas are characterised by a combination of forest and forest-edge habitats that support the natural reservoir hosts, and humid, temperate microclimatic ground-level conditions that favour I xodes spp. ticks in all stages of their development (6). In Europe, Lyme disease risk is associated with forestry work and with residence and leisure activities in rural areas, but not in those areas devoted to intensive agriculture (7).

In G ermany, rates of tick infectivity range from $10 \%$ to $40 \%(8)$. One survey in southeast Bavaria found that $11 \%$ of blood donors harboured antibodies to B. burgdorferi s.l., indicating previous exposure to the bacterium (9). It is estimated that in highly endemic areas of Germany, every tenth tick bite could lead to infection with B. burgdorferi s.l (8).

Human Lyme disease can affect all age groups of both sexes. Age-adjusted attack rates show a bimodal distribution, with the greatest risk of acquiring the disease being in children and middle-aged adults (10). 
Table 1. Principal clinical manifestations of Lyme disease (adapted from R eference 10).

\begin{tabular}{|l|l|l|l|}
\hline System & Stage 1 disease & Stage 2 disease & Stage 3 disease \\
\hline (C onstitutional) & $\begin{array}{l}\text { M alaise, fatigue, headache, } \\
\text { fever, arthralgias }\end{array}$ & Severe malaise and fatigue & Persistent fatigue \\
\hline Skin & Erythema migrans & Secondary annular lesions & $\begin{array}{l}\text { Acrodermatitis chronica } \\
\text { atrophicans }\end{array}$ \\
\hline M usculoskeletal & M yalgias / arthral gias & $\begin{array}{l}\text { M igratory musculoskeletal } \\
\text { pains }\end{array}$ & $\begin{array}{l}\text { Intermittent oligoarthropathy, } \\
\text { periostitis / joint subluxations } \\
\text { below acrodermatitis lesions }\end{array}$ \\
\hline CNS & $\begin{array}{l}\text { M eningitis, cranial } \\
\text { neuropathy, radiculoneuritis, } \\
\text { subtle encephalopathy }\end{array}$ & $\begin{array}{l}\text { Encephalomyelitis, } \\
\text { polyneuropathy, chronic } \\
\text { encephalopathy }\end{array}$ \\
\hline CVS & AV node block & Carditis \\
\hline
\end{tabular}

Vaccines have been developed against North American strains of $B$. burgdorferi, and one randomised controlled trial found that, compared with placebo, three doses of a vaccine based on the Outer Surface Protein A reduces the incidence of Lyme disease in adults resident in endemic areas of $\mathrm{N}$ orth America (10). There is no good evidence regarding the effects of $L$ yme disease vaccines in Europe and Asia, and because of the diversity of $\mathrm{B}$. burgdorferi species on these two continents, North American vaccines are likely to be ineffective (1).

Lyme disease is generally transmitted to humans during the summer months. M ost human cases are diagnosed between July to November, and the usual peak incident month is August (12).

\section{Pathogenesis}

Lyme disease consists of an inflammatory process with non-specific histological changes; the most striking of these changes are in the joints, in both the acute and chronic stages of the disease (13). Stains of EM lesions reveal a perivascular mononuclear infiltrate and fibrin deposition in the dermis, without epidermal changes except at the site of the bite (14).

The causative agent of Lyme disease is extremely sparse in infected tissue and is difficult to identify, even in stained sections. Spirochaetes have been visualised in skin lesions, heart tissue and synovium, but not

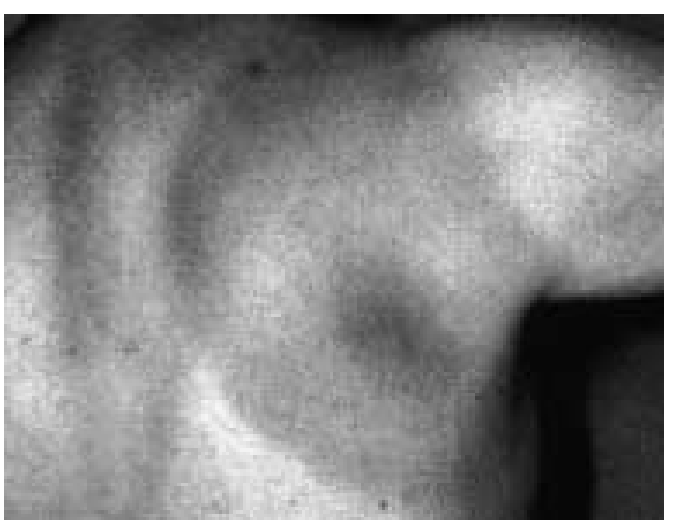

Fig2. Erythema migrans, or EM ( Centers for Disease Control) in peripheral nerves, where it has been postulated that an autoimmune mechanism accounts for the inflammatory lesions (15).

\section{Clinical features}

The one sign that enables a reliable clinical diagnosis of early $L$ yme disease to be made is the characteristic bull's eye rash (Figure 2) known as erythema migrans, or EM . This develops between 3 and 30 days (typically 7 to 14 days) after an infected tick bite (14).

Following inoculation of $\mathrm{B}$. burgdorferi, infection may spread by the cutaneous, lymphatic or haematogenous routes (14). The principal clinical manifestations of $B$. burgdorferi infection are summarised in Table 1.

L yme disease sequelae occur in untreated people, some weeks or months following the primary inoculation with B. burgdoferi (17).

These sequelae present with the following frequencies:

- Arthritis. D evelops in 50\% of untreated people (1). Typically this is an intermittent oligoarthropathy, usually involving one large, weight-bearing joint (most commonly, the knee) (13). For a military workforce, this has obvious occupational health implications.

- M eningitis or neuropathies. D evelop in $15 \%$ of untreated people (1). In addition, a chronic encephalopathy can develop, with memory deficit, sleep disturbance, persistent fatigue and personality disorders (14).

- Carditis. Develops in $5-10 \%$ of untreated people (1).

$M$ iddle-aged and elderly sufferers from Lyme disease, if untreated, are especially prone to develop a painful radiculoneuritis, formerly known as "Bannwarth syndrome". This has an incubation period of 7 weeks in adults and 4 weeks in children. In adults, this disorder often presents as a triad, which includes radicular pain, peripheral pareses (most frequently a facial palsy) and a lymphocytosis in the cerebrospinal fluid (12). The pain syndrome is often intense, such that one-third of patients with the 
syndrome may become depressed, agitated and anxious, and some patients with pain alone have been certified insane due to personality changes and misdiagnosis (18).

In our series two patients ( $C$ ases Two and Three) reported visual disturbances. This sequela of Lyme disease is not commonly mentioned in standard textbooks of infection, although it is well described in the specialist literature (19-21). Again, it has important occupational health implications.

\section{Diagnosis}

The diagnosis of Lyme disease is usually obvious if there is a history of recent tick bite in an endemic area (13).

In patients where the history is unclear, and especially where there appears to be extracutaneous involvement, serological testing should be carried out for antibodies to $B$. burgdoferi (22). I gM antibodies can be detected within about 2 weeks of infection, the peak usually occurring between the third and sixth week. By 6 weeks or more, the level of IgG is usually raised (13).

Serum antibodies often persist for months or years following treated and untreated Lyme disease, and serological reactivity cannot, therefore, be used as a marker of disease activity (14). On the other hand, seronegativity is not necessarily a bar to the diagnosis of $L$ yme disease, since due to the genetic heterogeneity of the $B$. burgdorferi species complex, serodiagnosis is not $100 \%$ sensitive (13). This diagnostic challenge is demonstrated in Case Two of our series.

Since serodiagnosis early in $L$ yme disease infection is particularly difficult, even the most sensitive tests may be negative. When serologic testing is indicated, the US $C$ entres for $D$ isease $C$ ontrol and Prevention recommend testing initially with a sensitive first test, either an enzyme-linked immunosorbent assay (ELISA) or an indirect fluorescent antibody (IFA) test, followed by testing with the more specific Western immunoblot test to corroborate equivocal or positive results obtained with the first test (23).

Treatment

Treatment with antibiotics is beneficial for all stages of Lyme disease, but is most successful early in the course of the illness (24). Patients in whom the central nervous system is affected should be treated with intravenous antibiotics; oral antibiotics are usually sufficient for most other manifestations.

Table 2 shows the recommended treatment regimens for British Forces Germany. These recommendations, which are revised annually, are based on the best available research evidence (1).

\section{Conclusions}

Lyme disease presents with diverse clinical signs and symptoms, and with several variations in the course of the disease.

The outdoor lifestyle of British military personnel and their dependants exposes them to infective ticks and it is likely that some military patients with typical clinical signs remain undiagnosed and untreated. A high index of clinical suspicion, and prompt treatment with an antibiotic, is essential in these cases.

Targeted education on the primary prevention of $L$ yme disease (that is, through avoiding exposure to tick bites) is mandatory for military employers.

\section{Acknowledgements}

We thank $\mathrm{Mr}$ M ichael Quarrell, of the Secondary Healthcare Admin Centre, Bielefeld, for his help in retrieving the discharge summaries of the four patients described in this paper.

\section{References}

1. Hayes E. Lyme disease. In: Barton S, ed. Clinical evidence - the international source of the best available evidence for effective health care. London: BM J Publishing G roup, 2004.

2. H awker J, Begg N, Blair I, Reintjes R, Weinberg J Communicable disease control handbook. Oxford: Blackwell Science, 2001.

3. Reimer B, Erbas B, L obbichler $\mathrm{K}$, Truckenbrodt $R$, G artner-K othe $U, K$ apeller $N$, et al. Seroprevalence of Borrelia infection in occupational tick-exposed people in Bavaria (Germany). Int J M ed M icrob 2002; 291 Suppl 33: 215.

4. Gern L, Estrada-Pena A, Frandsen F, Gray JS Jaenson T GT, Jongejan $F$, et al. European reservoir hosts of B orrelia burgdorferi sensu lato. Zentralblatt für B akteriologie 1998; 287: 196-204.

Table 2. Lyme disease - recommended treatment regimens for B ritish F orces $G$ ermany.

\begin{tabular}{|c|c|c|c|c|}
\hline Patient category & First line choice & Second line choice & Third line choice & Fourth line choice \\
\hline $\begin{array}{l}\text { Adult males and } \\
\text { non-pregnant } \\
\text { women }\end{array}$ & $\begin{array}{l}\text { doxycycline } 100 \mathrm{mg} \\
\text { bd, for } 10 \text { days ( } 20 \\
\text { days if recurrence) }\end{array}$ & $\begin{array}{l}\text { tetracycline } 200 \mathrm{mg} \\
\text { qds, for } 10-20 \text { days }\end{array}$ & & \\
\hline Pregnant & $\begin{array}{l}\text { amoxycillin } 25 \mathrm{mg} / \mathrm{kg} \\
\text { / day in } 3 \text { divided doses, } \\
\text { for } 14-28 \text { days }\end{array}$ & $\begin{array}{l}\text { phenoxymethylpenicillin } \\
50 \mathrm{mg} / \mathrm{kg} / \text { day in } 4 \\
\text { divided doses, for } 14-28 \\
\text { days }\end{array}$ & $\begin{array}{l}\text { cefuroxime acetil } \\
500 \mathrm{mg} \text { bd, } \\
\text { for } 10-30 \text { days }\end{array}$ & $\begin{array}{l}\text { erythromycin } \\
250 \mathrm{mg} \text { qds, for } \\
10-30 \text { days }\end{array}$ \\
\hline $\begin{array}{l}\text { C hildren under } \\
12 \text { years }\end{array}$ & $\begin{array}{l}\text { amoxycillin } 25 \mathrm{mg} / \mathrm{kg} \\
\text { / day in } 3 \text { divided doses, } \\
\text { for } 14-28 \text { days }\end{array}$ & $\begin{array}{l}\text { phenoxymethylpenicillin } \\
50 \mathrm{mg} / \mathrm{kg} / \text { day in } 4 \\
\text { divided doses, for } 14-28 \\
\text { days }\end{array}$ & $\begin{array}{l}\text { erythromycin } \\
50 \mathrm{mg} / \mathrm{kg} / \text { day } \\
\text { in } 4 \text { divided doses, } \\
\text { for } 15-20 \text { days }\end{array}$ & \\
\hline
\end{tabular}


5. Schmid GP. The global distribution of Lyme disease. R eview of I nfectious D iseases 1985; 7: 41-50.

6. Fish D. Environmental risk and prevention of Lyme disease. A m J M ed 1995; 98 (4A):25-95.

7. Gray J. Risk assessment in Lyme borreliosis. W iener K linischeWochenscrift 1999; 111 990-993.

8. K immig $\mathrm{P}, \mathrm{O}$ ehme $\mathrm{R}, \mathrm{B}$ acke $\mathrm{H}$. E pidemiologie der F rühsommer-M eningoenzephalitis (FSME) und Lyme-Borreliose in Südwestdeutschland. Ellipse 1998; 14: 95-105.

9. O'C onnell S, Granstrom M, Gray JS, Stanek G. Epidemiology of European Lyme borreliosis. Zentralblatt für B akteriologie 1998; 287: 229-240.

10. Steere AC. L yme disease. N Engl J M ed 1989; 321. 586-590.

11. Steere AC, Sikand VJ, M eurice F, Parenti DL, Fikrig $E$, Schoen RT, et al. Vaccination against Lyme disease with recombinant Borrelia burgdorferi outer-surface lipoprotein $A$ with adjuvant. N Engl J M ed 1998; 339: 209-215.

12. $K$ ristoferitsch $W$, Sluga $E, G$ raf $M$, Partsch $H$, N eumann R, Stanek G, Budka H. N europathy associated with acrodermatitis chronica atrophicans: clinical and morphological features. A nnals of the $\mathrm{N}$ ew York A cademy of Sciences 1989; 539. 35-45.

13. Cook GC. Other spirochaetal diseases (excluding Treponema spp and Leptospira spp). In: Cook GC, Zumla Al, eds. M anson's tropical diseases. 21st ed. L ondon: Saunders, 2003.

14. Steere AC, M alawista SE, H ardin JA, Ruddy S, Askenase PW, Andiman WA. Erythema chronicum migrans and $L y m e$ arthritis. T he enlarging clinical spectrum. A nn Intern M ed 1977; 86: 685-698.
15. Sivadas R, Rahn DW, Luft BJ. Lyme disease. In: C ohen J, Powderly WG, eds. Infectious diseases. 2nd ed. London: M osby, 2004: 591-604.

16. Dennis T, Strickland GT. Lyme disease. In: Strickland GT, ed. H unter's tropical medicine and emerging infectious diseases. 8th ed. London: WB Saunders, 2000

17. Nadelman RB, Wormser GP. Lyme borreliosis. Lancet 1998; 352: 557-565.

18. Stanek G, Strle F, Gray J, Wormser GP. H istory and characteristics of $L$ yme borreliosis. In: G ray J, $\mathrm{K}$ ahl O, Lane RS, eds. Lyme borreliosis - biology, epidemiology and control. New York: CABI Publishing, 2002: 1-28.

19. Bertuch AW, Rocco E, Schwartz EG. Eye findings in L yme disease. Conn M ed 1987; 51 151-152.

20. Jager $M, K$ uiper $H$. Aspecific eye disorders in L yme disease. N ed Tijdschr $G$ eneeskd 1991; 135: 1500-1502.

21. Bialasiewicz AA. Eye manifestations of Lyme borreliosis. O phthalmologe 1992; 89. W 47-W 59 .

22. Halperin JJ. Lyme neuroborreliosis. In: Cuhn BA, ed. Tickborne infectious diseases: diagnosis and management. N ew York: D ekker, 2000.

23. Centers for D isease Control. Recommendations for test performance and interpretation from the Second International Conference on Serologic Diagnosis of $L$ yme Disease. M orb M ortalW kly Rep 1995; 44: 1-5.

24. Stanek G, Strle F. Lyme borreliosis. Lancet 2003; 362: 1639-1647. 